\section{FOR INTERNATIONAL GOOD-WILL DAY}

W HEN children's friendships are world-wide, New Ages will be glorified"- so said the men and women who first suggested the celebration of International Good-Will Day; so we are all coming to see and say. Last year May 18 , was celebrated in more school-rooms than ever before. This year the number will probably be doubled. The International Relations Committee of the National Council of Teachers of English offers to English teachers of older boys and girls the following program material. Let's make the day an unforgettable one!

\section{Songs}

1. A Vision of Friendship, The Light of Peace-By E. B. Allen for the International Relations Committee of the National Cocuncil of English. Address E. Estelle Downing, Ypsilant;, Michigan. Each song 50c per hundred.

2. Ain't Goin' Study War No Mo'-By B. G. Ricordi. In Across Burderlines. Address I.

3. The Banner of Peace-By D. Batchellor. In Across Borderlines. Address I.

4. Peace Hymn of the World-By C. C. Woods. In Across Borderlines. Address I.

5. Song of Peace-By M. K. Schemerhorn. In Through the Gateway. Address I.

6. Young Crusaders for Peace-By D. Batchellor. In Through the Gateway. Address I.

7. Hymn for Universal Peace-By Evelyn Leeds Cole. Address 307 N. Elm Avenue, Jackson, Michicgan. 10c.

8. It Must Not be Again-By J. G. Dailey. Address 4734 Kingsissing Avenue, Philadelphia. Two copies, 25c, \$1. per dozen.
9. Seven American Songs of Peace and Pariotism- By C. H. Congdon. Address 200 Fifth Avenue, New York City.

10. Folk Songs of Many Peoples. Two volumes. Includes pictures and directions for accompanying dances. Address II.

Topics for Short Talks or Essays

1. Why the United States cannot be a Robinson Crusoe among nations.

2. How some cartoonists are helping on World Good Will.

3. Why every schoolroom should have a copy of Bishop Oldham's Creed for Americans. Address I for a copy.

4. How Richard Rush secured the world's first unarmed boundary line. Story in Across Borderlines. Address I.

5. The world's honor roll of heroes. Address I for information about World Hero Calendar.

6. Best ways of honoring our dead soldiers.

7. Why high school students should read Private Peat's The Inexcusable Lie. Address Donneley, Chicago.

8. What the League of Nations really is and does. Address I.

9. How animals and insects coöperate for mutual aid. Material in Across Borderlines. Address I.

10. Organizations working for World Peace. Address I.

11. The scrap-book project.

12. How the Junior Red Cross is helping on the cause of World Peace. Address Washington, D. C.

13. International House - Where and What it is. Address H. E. Edmonds, 500 Riverside Drive, New York City.

14. The essay contest based on Polleck's The Enemy. Address Scholastic, Wabash Building, Pittsburgh. 
15. What our school can do to promote world good-will.

\section{Poems}

1. The Placard-By "Damon." In Poems of the War and the Peace. Address III.

2. German Prisoners-By Joseph Lee. In Poems of the War and the Peace. Address III.

3. To Germany-By C. H. Sorely. In Poems of the War and the Peace. Address III.

4. The Pied Piper-By William E. Leonard. In Poems of the War and the Peace. Address III.

5. The Debt-By E. V. Lucas. In Poems of the War and the Peace. Address III.

6. Abraham Lincoln Walks at Midnight -By B. Vachel Lindsay. In Poems of the War and the Peace. Address III.

7. Clean Hands-By Austin Dobson. In Poems of the War and the Peace. Address III.

8. 1914 and After-By James Oppenheim. In Poems of the War and the Peace. Address III.

9. The Battle of Blenheim-By Robert Southey. In Poems of the War and the Peace. Address III.

10. The Arsenal at Springfield-By H. W. Longfellow.

11. Abou Ben Adhem-By Leigh Hunt.

12. The Fatherland-By J. R. Lowell.

13. A Hymn of Peace-By O. W. Holmes.

14. A Vista-By J. A. Symonds.

15. Brotherhood-By Edwin Markham. In Man with Hoe.

16. Excerpt from Longfellow's Hiawatha, beginning "Gitchie Manito, the mighty, The creator of the nations."

17. Excerpt from Tennyson's Locksley Hall, beginning, "For I dipt into the future."
18. Excerpt from Pope's "The Messiah," beginnig, "No more shall nation against nation rise."

19. Excerpt from Milton's "Paradise Regained," beginning, "They err who count it glorious to subdue."

20. Excerpt from Whittier's Disarmament, beginning, "There is a story told."

21. The Illusion of War-By Richard LeGalliene. In Across Borderlines. Address I.

22. Buttons - By Carl Sandburg. In Across Borderlines. Address I.

23. The Land Where Hate Should DieBy Denis McCarthy. In Across Borderlines. Address I.

24. Midnight-the 31 of December-By Stephen Phillips. In Across Borderlines. Address I.

25. The Dawn of Peace-By Alfred Noyes. In Across Borderlines. Address I.

26. We Mothers Know-By John Drinkwater. In The Peace Primer. Address IV. 25c.

27. Peace-By Harriette T. Richardson. In The Peace Primer. Address IV.

28. The New City-By Marguerite Wilkinson. In Lyman and Hill's Literature and Living, Volume III. Address VIII.

29. The Need for Men-By J. G. Holland. In Lyman and Hill's Literature and Living, Volume III. Address VIII.

Stories for Telling or Dramatizing

1. Peace Through Justice-By Henriette Kuyper. In Never Again. Address IX.

2. Lay Down Your Arms-By Marion Rittenhouse. In Never Again. Address IX.

3. Kato's Revenge-By A. A. Bennett. In Never Again. Address IX.

4. Never Again-By Margaret Applegate. In Never Again. Address IX. 
5. The Perfect Tribute-By M. R. S. Andrews. In Lyman and Hill's Literature and Living, Volume III. Address VIII.

6' The Other Wise Man-By Henry Van Dyke. In Lyman and Hill's Literature and Living, Volume III. Address VIII.

7. The Christ of the Andes-By Caroline Duidboro. In Lyman and Hill's Literature and Living, Volume III. Address VIII.

8. Jean Val Jean and the Bishop-By Victor Hugo. In Lyman and Hill's Literature and Living, Volume III. Address VIII.

9. How Richard Rush had his Chance. In Through the Gateway. Address I.

10. Binyon's Paths of Peace--two volumes - contains much good material. Address Oxford University Press, $35 \mathrm{~W}$. 32nd St., New York City.

\section{Readings and Declamations}

1. What Makes a Nation-By Wilbur D. Nesbit. In Lyman and Hill's Literature and Living, Volume III. Address VIII.

2. America-By Franklin Lane. In Lyman and Hill's Literature and Living, Volume III. Address VIII.

3. An American Creed-By Charles W. Eliot. In Lyman and Hill's Literature and Living, Volume III. Address VIII.

4. Four Things-By Henry Van Dyke. In Lyman and Hill's Literature and Living, Volume III. Address VIII.

5. The True Grandeur of Nations--By Charles Sumner

6. The Vision of Peace-By Nathan H. Dolo

7. A Society of Nations-By Woodrow Wilson

8. America's Unknown Soldier-Warren G. Harding

9. Brotherhood-Edwin Markham
10. America and the World - George Washington

11. The Union-Alfred Noyes

12. The Boy Scout's Code-Arthur Carey

13. You are the Hope of the World-Herman Hagedorn

14. Your Best and Hardest Job-Hildegarde Hagedorn

15. The All-Nation Football Team-Basil Matthews. In Across Borderlines. Address I.

16. An Adventure in Inter-racial Friendship-By Lincoln Wirt. In Across Borderlines.

17. A Letter Across the Borderline. In Across Borderlines. Address I.

18. Temporary Cannibalism-By E. M. Root-In Across Borderlines. Address I.

19. The Fight of the Future-By Basil Matthews - In Across Borderlines. Address I.

20. Twenty excellent selections by famous people in Selections published for Prince of Peace Declamation Contest. Address Ohio Council of Churches, 415 Outlook Bldg., Columbus, Ohio. Price $15 \mathrm{c}$. Excellent.

\section{Plays and Pageants}

1. They Just Won't Talk-By Katherine Reely for International Relations Committee of National Council of Teachers of English. One act. Pointed and pleasing. Adress E. Estelle Downing, Ypsilanti, Michigan. 10c a copy. Suited for high school.

2. The Loom of Freedom-By W. Maroney. A pageant of the nations. Address II.

3. Hope of All the World-By Bradfield. A splendid pageant play based on the League of Nations. Address VII.

4. Youth and the World They Live inBy Aylmer. Based on the procedure of the League of Nations Assembly. 
Informational and interesting. Address VII.

5. Serving the world. Given by girl scouts at the International Conference of Girl Guides and Scouts held in New York in May. Simple but effective. No charge. Address VII.

6. The Gate of the West. (A dramatization of "Scum o' the Earth.")-In Ritual and Dramatized Folk Ways, Jasspon and Becker. Address Century Co., 353 Fourth Ave., New York City.

7. The Enemy-By Channing Pollock. Very vivid, human and dramatic play based on the idea that the common enemy of all men is hate. Amateurs may give readings from the play by writing Mr. Pollock at 229 W. 42nd St., New York. The Play is published by Brentano's in New York.

8. Uncle Sam's Choice-By Anna C. Evans. Emphasizes the vast expenditures for war. A short, snappy play. In Across Borderlines. Address I.

9. Fruits of Civilization. A series of tableaux which can be adapted to suit stage and time limit. Has possibilities of real effectiveness and beauty. Could be made an entire program. In Across Borderlines. Address I.

10. Cantata for Peace Day-By Fannie Fern Andrews and John Donovan. Eight songs-several of them familiar poems. Address John Church Co., Cincinnati. Price 40 cents.

11. America for Americans-By Katherine Cronk. A humorous play based on the idea that we are debtors to all lands. High school students like it. Address Lit. Headquarters, 723 Muhlenberg Bldg., 1228 Spruce St., Philadelphia. Price 15c.

12. The Triumph of Peace-Anita Ferris. For senior high schools. 35 characters. Time 1 hour. Address Missionary
Education Movement, 150 Fifth Avenue, New York City. Price 15 cents.

\section{List of Addresses}

1. National Council for the Prevention of War, 532 Seventeenth Street, N. W., Washington, D. C.

2. Woman's Press, 600 Lexington Ave., New York City.

3. Harcourt Brace, New York City.

4. Mrs. E. K. Bowman, Helena, Montana.

5. National Child Welfare Asso., 70 Fifth Avenue, New York City.

6. American School Peace League, 405 Marlborough St., Boston, Mass.

7. League of Nations Non-Partisan Asso., 6 E. 39th St., New York City.

8. Scribner's Pub. Co., New York City.

9. Everyland Pub. Co., West Medford, Mass.

\section{E. Estelle Downing}

\section{A FIFTH GRADE PLAN IN ART}

\section{Preliminary Data}

Time allowance: Two sixty-minute periods. Major unit: Principles of spacing, balance, subordination, and perspective.

Minor unit: Thanksgiving pictures of black and white cut paper; the children's previous work shows need of further training in subordination.

Material: Book of pictures drawn with colored crayons by school children in Japan; pictures in black and white cut paper made by former classes in the Training School; blackboard sketches illustrating the "center of interest," or subordination; black and white cut paper models for graphic vocabulary-Indian man, Indian woman, Pilgrim man, Pilgrim woman, turkey, deer, and boat. 